\title{
Serological investigation of some important RNA viruses affecting sheep and goats in Giza and Beni-Suef governorates in Egypt
}

\author{
Mohamed Abd El-Fatah Mahmoud ${ }^{1}$, Mohamed Karam Elbayoumy ${ }^{1}$, Doaa Sedky ${ }^{1}$ and Sahar Ahmed ${ }^{2}$ \\ 1. Department of Parasitology and Animal Diseases, Division of Veterinary Research, National Research Centre, 12622 \\ Dokki, Giza, Egypt; 2. Department of Cell Biology, Division of Genetic Engineering \& Biotechnology, National Research \\ Centre, 12622 Dokki, Giza, Egypt. \\ Corresponding author: Mohamed Abd El-Fatah Mahmoud, e-mail: m_elfatatri@yahoo.com \\ Co-authors: MKE: mhdkaram@hotmail.com,DS: doaa_sedky@yahoo.com, SA: selnahta@yahoo.com \\ Received: 18-05-2017, Accepted: 07-09-2017, Published online: 02-10-2017
}

doi: 10.14202/vetworld.2017.1161-1166 How to cite this article: Mahmoud MAE, Elbayoumy MK, Sedky D, Ahmed S (2017) Serological investigation of some important RNA viruses affecting sheep and goats in Giza and Beni-Suef governorates in Egypt, Veterinary World, 10(10): 1161-1166.

\begin{abstract}
Aim: The aim of this study was to investigate the seroprevalence of antibodies against foot and mouth disease (FMD), Peste des Petits ruminants (PPR), and bluetongue (BT) in sheep and goats within Giza and Beni-Suef governorates at the second half of 2016.

Materials and Methods: A total of 300 animals (sheep and goats) randomly selected from small stocks with no history of previous vaccination against FMD virus (FMDV), PPR, or BT viruses (BTV) and examined with competitive enzymelinked immunosorbent assay for detection of FMD-non-structural protein, PPR, and BT antibodies.

Results: Seroprevalence analysis revealed that antibodies against FMDV were $40.8 \%$ and 37.1\% at Giza governorate, while at Beni-Suef governorate, the percent was $36.7 \%$ and $50 \%$ in sheep and goat, respectively. Antibodies against PPR were $63.8 \%$ in sheep and $45.7 \%$ in goats at Giza governorate, whereas the results for Beni-Suef governorate were $71.7 \%$ in sheep and $45 \%$ in goats. Antibodies against BT were $45 \%$ and $37 \%$ in sheep and goats, respectively, in Giza governorate, whereas the results for Beni-Suef governorate were $80 \%$ and $55 \%$ in sheep and goats, respectively. The average of BTV antibody prevalence was significantly higher in sheep (45\% and 80\%) than in goats (37\% and 55\%) in Giza and Beni-Suef, respectively. Statistical analysis for the three viruses showed the high relation between the two governorates in case of sheep $(\mathrm{r}=0.85)$ and in case of goats $(\mathrm{r}=0.87)$. In general, a strong positive correlation was observed between the governorates $(\mathrm{r}=0.93)$.
\end{abstract}

Conclusion: Giza and Beni-Suef governorates are endemic with FMDV, PPR, and BTV. Regional plan for characterization and combating FMD, PPR, and BT is recommended to help in the achievement of the most suitable combination of the vaccine regimen.

Keywords: bluetongue, enzyme-linked immunosorbent assay, foot and mouth disease, goats, Peste des Petits ruminants, sheep.

\section{Introduction}

Small ruminants mainly sheep and goats contribute significantly to the economy of farmers in African and Asian countries. Sheep and goats are a source of meat, milk, and wool in addition to their rapid growth and reproduction. Poor man considers goats as cows in developing countries [1].

In Egypt, sheep and goats play a dynamic role in the economy of poor, destitute, and landless workers. Many viral diseases attack sheep and goats, namely, foot-and-mouth disease (FMD), bluetongue (BT) disease, maedi-visna, orf, tick-borne encephalomyelitis, Peste des Petits ruminants (PPR), sheep pox, and goat pox $[2,3]$.

\footnotetext{
Copyright: Mahmoud, et al. Open Access. This article is distributed under the terms of the Creative Commons Attribution 4.0 International License (http://creativecommons.org/licenses/ by/4.0/), which permits unrestricted use, distribution, and reproduction in any medium, provided you give appropriate credit to the original author(s) and the source, provide a link to the Creative Commons license, and indicate if changes were made. The Creative Commons Public Domain Dedication waiver (http:// creativecommons.org/publicdomain/zero/1.0/) applies to the data made available in this article, unless otherwise stated.
}

FMD virus (FMDV) is a positive, single-stranded RNA virus, a member of family Picornaviridae $[4,5]$. It is a highly transmissible disease of both wildlife and house-trained even-toed animals. More than 65 wild animal species are susceptible to FMD infection [6].

Serologically, seven serotypes of the virus were identified as O, A, Asia 1, C, SAT 1, SAT 2, and SAT 3, and each serotype has multiple subtypes [7]. The viral particles present in all discharges and secretions of sick animals, so the virus spreads efficiently. Infection occurs through the exposure to the contaminated materials either directly or indirectly [8]. Control of FMD infection is so difficult as the wind can spread the virus for a distance of $10 \mathrm{~km}$ [9]. There is no cross-protection against different FMD serotypes [10].

The disease characterized by a low mortality rate (5\%) and high morbidity rate (100\%) in adult animals. FMD is responsible for the production losses represented by low milk yield and weight loss [11].

FMDV genome is $8.5 \mathrm{~kb}$ naked RNA virus, and this genome codes for structural protein (SPs) and 
non-SPs (NSPs). Although, antibodies against both SPs and NSPs could be detected in infected animals, and antibodies against NSPs are not present in vaccinated not infected animals [12]. Hence, in using kits that can identify antibodies against NSPs, we can differentiate diseased animals from vaccinated one [13].

PPR causes discrete financial troubles in sheep and goats farms [14]. PPR virus attacks sheep and goats and leads to pneumoenteritis [15]. PPR virus is a member of genus morbillivirus, Paramyxoviridae [16]. Four lineages (I, II, III, and IV) of PPR virus were identified on sequencing of the fusion $(\mathrm{F})$ protein [17]. Epidemiologically, PPR prevails mainly in Africa and Asia [18]. The PPR viral particles present in all secretions and discharges of the diseased animal [19]. The disease causes high morbidity and mortality rates reach to $100 \%$ in highly susceptible animals [20].

BT is an infectious arthropod-borne viral disease of sheep and goats. BT virus (BTV) has an RNA genome of double-stranded nature (genus Orbivirus and family Reoviridae) which attacks housetrained and wild ruminants [21]. 24 separate BTV serotypes have been recognized for decades, and all of them can initiate the infection in ruminants. However, two new BTV serotypes, BTV-25 (Toggenburg orbivirus, from Switzerland) and BTV-26 (from Kuwait), were recently registered in goats and sheep, respectively [22].

The disease affects fine wool and mutton breeds of sheep severely; cattle represent the chief mammalian reservoir of the BTV and play a very important role in the epidemiology of the disease [23]. The virus infects goats and wild ruminants but generally with mild or no clinical signs. Culicoides mainly transmit BTV beside the oral and vertical route in sheep and cattle. Epidemiologically, BT disease is common in humid areas of the world with no clear symptoms in the native sheep populations [24]. The distribution of BT is constrained to a latitudinal band around the world between $50^{\circ} \mathrm{N}$ and $30^{\circ} \mathrm{S}$ of the world where Culicoides midges are tremendously abundant [25].

Clinical signs of the sickness are usually clear in sheep and some uninhabited ruminants but are rare in goats and cattle. Symptoms vary from subclinical to acute febrile response; it causes facial edema and hemorrhages, ulceration of the mucous membranes. There is often severe muscle degeneration and skeletal myopathy [26].

In Egypt, BTV infection was recognized for the first time in foreign Marino sheep [27]. The identified BTV serotypes in the succeeding epidemics were BTV 1, 4, 10, 12, and 16 [28]. Mahmoud and Khafagi [23] conducted a serosurvey on samples collected from 14 governorates of the upper and lower Egypt. About $17.5 \%$ of sheep and $14.7 \%$ of goats' serum samples were positive. In all tested governorates, the prevalence of BT antibodies was $17.5 \%$ in sheep and $14.7 \%$ in goats. The overall prevalence of anti-BT antibodies in different governorates was $16.9 \%$. Giza and BeniSuef governorates recorded the highest prevalence of
BT group specific antibodies with 30\% (24/80) and $71.8 \%$ (74/103) in Giza and Beni-Suef governorates, respectively.

This study aimed to investigate the seroprevalence of antibodies against FMD, PPR, and BTVs in sheep and goats within Giza and Beni-Suef governorates. Examined sheep and goats express the environment of sheep and goat holders with small numbers, group-housed with cattle and buffaloes and not comply with any immunization programs even if present.

\section{Materials and Methods}

\section{Ethical approval}

Ethical approval from Institutional Animal Ethics Committee and local laws and regulations were considered in applying our experiment.

\section{Animals}

A total of 300 serum samples from sheep and goats were collected from AL-Hawamdia district-Giza Governorate and Kafr Abo Qassim-BeniSuef Governorate in the second half of 2016. Selected animals in this study reared in association with both buffaloes and cattle.

Animals were randomly selected from small stocks that do not apply vaccination against FMDV, PPR, and BTVs, and there is no history of previous vaccination. Types and numbers of animals examined in each governorate distributed according to Table-1.

\section{Serum preparation}

Blood samples were collected aseptically from the jugular vein from each animal using plain vacutainer tubes. Serum was separated by centrifugation of the blood at $3000 \mathrm{rpm}$ for $10 \mathrm{~min}$ at room temperature; aliquots were transferred into a $1.5 \mathrm{ml}$ sterile microcentrifuge tube. All serum samples were stored at $-20^{\circ} \mathrm{C}$ until used for a serological investigation [29].

\section{Detection of FMD NSP antibodies}

Serum samples were used to monitor antibody against non-structural polyprotein (NSP) $3 \mathrm{ABC}$ of FMD antigen using marketable enzyme-linked immunosorbent assay (ELISA) kit (IDEXX FMD 3ABC $\mathrm{Bo}-\mathrm{Ov}$ ), and we followed the manufacturer instructions. According to the ELISA test kit manual, samples with percentage values $>30 \%$ were considered positive, $<20 \%$ as negative, and samples between $20 \%$ and $30 \%$ were considered suspicious [30].

\section{Detection of PPR antibodies using competitive ELISA (cELISA)}

cELISA kit and its protocol provided by IAH (Pirbright Laboratory, UK). The test is depending on the competition between the monoclonal antibody $(\mathrm{MAb})$ against the tested serum antibodies for binding to the $\mathrm{H}$ protein antigen [31]. Serum antibodies compete with the enclosed MAb to fix to the coated plate. The test was carried out according to the supplied protocol. Both the negative and positive cutoff values were utilized from the controls of the test 


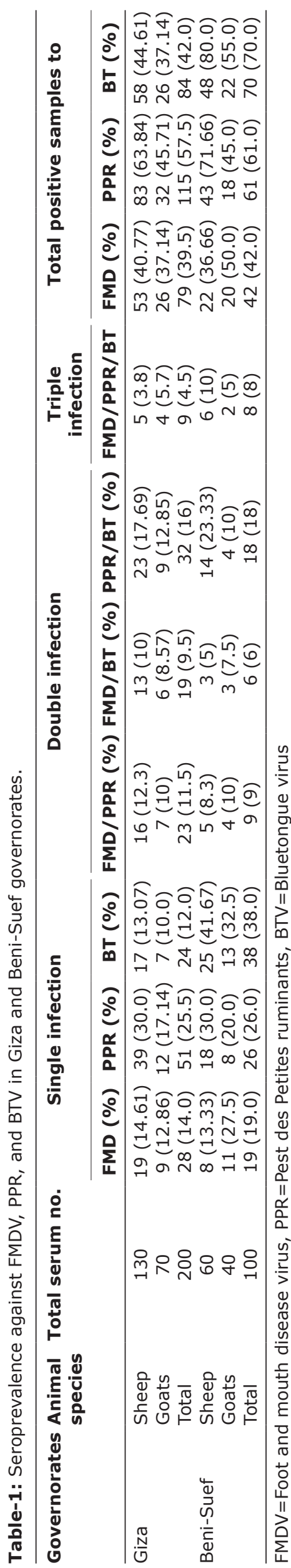

procedure. Using Immunoskan reader produced by Flow Laboratories, UK, we read the ELISA plates at $492 \mathrm{~nm}$ wavelength filter. Calculation of the result was gotten automatically by the aid of installed software on a computer connected to the reader. This software is produced by FAO/IAEA, Vienna, Austria, and calculates percentage inhibition (PI) values directly. The optical density (OD) values could be changed to PI by the following formula:

$$
\mathrm{PI} \%=100-\frac{\text { Mean OD of test wells }}{\text { Mean OD of cma wells }} \times 100
$$

Where, $\mathrm{OD}=$ The optical density value, $\mathrm{cma}=$ The $\mathrm{MAb}$ control. Inhibition values more than $50 \%$ were considered positive.

\section{Detection of BT antibodies using CELISA}

cELISA Kit for detection of BT antibodies produced by BDSL, Biological Diagnostic Supplies Ltd., Surrey, UK was used. It is designed to detect the antibodies against the VP7 antigen. The test was carried out according to the supplied protocol. The PI values were calculated according to the formula of the study by Afshar et al. [32]. Samples that give PIs $\geq 50 \%$ were considered positive, and those with PIs of $<50 \%$ were negative.

\section{Statistical analysis}

Pearson correlation coefficients were calculated according to http://www.socscistatistics.com/tests/ pearson/Default2.aspx [33].

\section{Results and Discussion}

Small ruminants' livestock in Egypt is an easy and vulnerable target for many bacterial and viral epidemic diseases. Low efficiency existing control programs facilitate the spreading of different infectious and contagious diseases. A large number of viral diseases have the potential to cause serious losses in sheep and goats such as PPR, BT, and FMD.

In this study, we highlighted the serological prevalence of FMD, PPR, and BT in sheep and goats at Giza and Beni-Suef governorates, to clarify the epidemiological situation of the three viruses through evaluating its seroprevalence. Results of this study will be helpful for the decision-makers and stockholders.

As presented in Table-1 and illustrated in Figure-1, results revealed that the percent of serologically positive animals against FMDV was $40.8 \%$ and $37.1 \%$ at Giza governorate, whereas at Beni-Suef governorate, the percent were $36.7 \%$ and $50 \%$ in sheep and goat, respectively.

NSPs-FMD-dependent kits can identify antibodies to the NSP. Although this test can segregate the diseased animal from the immunized one, it cannot distinguish between the FMD serotypes [34].

Actually, buffaloes maintain FMD infections and infect other susceptible species in Sub-Saharan 


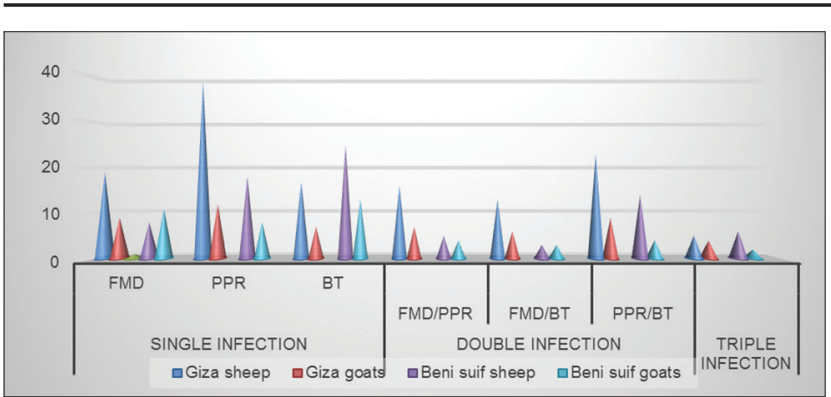

Figure-1: Comparison of single, double, and triple different viral infection in sheep and goats at Giza and Beni-Suef governorates.

Africa [35]. Natural and experimental transmission of FMD from carrier buffalo to cattle was confirmed [8].

Lots of positivity to FMDV indicates that the disease is endemic in the two governorates and also indicate that there are no major alterations between the prevalence of illness in sheep and goats. In fact, farmers raise sheep and goats together, so they have the same chances to pick up FMD and this is may be the reason for the non-significant difference in the prevalence of antibodies to FMDV. Comparable disease form was also documented in different reports. In Southern Jordan, the seroprevalence rates of FMD in sheep and goat at individual species level was reported to be $10.4 \%$ and $6.3 \%$, whereas seroprevalence at herd level was $44.7 \%$ and $33.3 \%$, correspondingly [36]. In Uganda, a positivity of $14 \%$ and $22 \%$ in goats and sheep, respectively, was reported [37]. In Pakistan, another serological study to NS proteins of FMD reported a positivity of $19.44 \%$ and $21.27 \%$ in sheep and goats, respectively. The overall seroprevalence rate was $21 \%$. The seroprevalence to the FMD-NSP in three different areas in Pakistan was $25.75 \%$, 4.75\%, and $32.5 \%$. The environment in which sheep and goats were raised was poor and represents a stress factor on the animals. Bad housing and the nutritional deficiency facilitate the spread of contagious diseases [38].

The difficulty of FMD recognition in sheep and goats and its numerous mobilizations play a role in the spreading of the disease between the susceptible animals [39]. Low infection within these farms combined with the findings of previous reports poses that the infected sheep and goats represent only a limited threat for FMD spread [40]. In endemic countries, in which mass vaccination is applying to all livestock, sheep and goats have only a partial role in the spreading of FMD infection. Meanwhile, it is desirable to include sheep and goats in the vaccination programs in FMD endemic republics or in countries that proceed to eradicate FMD [41]. Complete identification of the circulating FMD viral strains is essential to achieve the appropriate vaccine formula of good effectiveness [24].

Sheep are more resistant to PPR virus than goats, so it mounts a more humoral immunity $[42,43]$. Affected sheep with PPR are usually apparently normal [44]. Goats have a high liability to PPR that leads to death; therefore, the number of serologically positive goats to PPR are usually small [45].

Results showed that the rates of antibodies in sheep and goats sera against PPR were $63.8 \%$ in sheep and $45.7 \%$ in goats at Giza governorate, whereas the results for Beni-Suef governorate were $71.7 \%$ in sheep and $45 \%$ in goats. This may be due to the closeness of these regions to many neighboring villages, where PPR is endemic, and to the unrestricted movement of relatively large numbers of sheep and goats from these "endemic" regions into the surrounding districts.

There were poor data for the serological status of BTV in Egypt. The first serological survey was conducted by Hafez and Ozawa [27]. The overall ratio of BTV antibodies was (9\%) using the agar gel immune-precipitation test (AGPT), and the antibodies prevalence in ovine sera was $37 \%$. Mahmoud and Khafagi [23] conducted a serosurvey on samples collected from 14 governorates of the upper and lower Egypt; the overall prevalence of BT antibodies was $17.5 \%$ in sheep and $14.7 \%$ in goats. The overall prevalence of anti-BT antibodies in different governorates was $16.9 \%$. Giza and Beni-Suef governorates recorded the highest prevalence of BT group-specific antibodies, and in both governorates, the prevalence of BT antibodies was 30\% (24/80) and 71.8\% (74/103), respectively. In our study, antibodies prevalence in sheep and goats' sera against BT was $45 \%$ and $37 \%$ in sheep and goats, respectively, in Giza governorate, whereas the results for Beni-Suef governorate were $80 \%$ and $55 \%$ in sheep and goats, respectively. There is a significant variation between our results and that obtained by the findings of Mahmoud and Khafagi [23], Hafez and Ozawa [27]. This variation could be due to the variation in the used techniques, in our study, we depend on the ELISA technique, which is more sensitive than the AGPT that used by Mahmoud and Khafagi [23], Hafez and Ozawa [27].

The average of BTV antibody prevalence was significantly higher in sheep (45\% and $80 \%)$ than in goats (37\% and 55\%) in Giza and Beni-Suef, respectively; this is may be due to the low susceptibility of goats to natural infection with BT [46]. In addition, we selected sheep and goats mixed with cows and buffaloes. High prevalence of antibodies in the examined animals may be due to their presence next to cows, which is the main reservoir of the BTV. Mixed breeding between different species of livestock is an obstacle in the control operations and a means of transmitting diseases between these species [47].

The animal susceptibility to the virus infection is exaggerated by many epidemiological factors such as fitness, spreading of the vector and feeding behaviors of the vector, and older animals tend to be more liable than younger ones. The severity of symptoms looks to vary according to the animal breed and the viral serotype [48].

Statistical analysis showed a high correlation between the two governorates in case of sheep $(\mathrm{r}=0.85)$ and in case of goats $(\mathrm{r}=0.87)$. In general, a 
strong positive correlation was observed between the two governorates; the value of $r=0.93$. The value of $r^{2}$, the coefficient of determination, is 0.8636 .

The reported seroprevalence of FMD with BT in sheep and goats was high. Serotyping of the FMDV and BTVs within the Egyptian governorates specially Giza and Beni-Suef governorates is recommended. We concluded banning of importation from the endemic areas by such viruses, in addition to respectable checking and accreditation at the quarantine checkpoints.

As shown in Table-1 and illustrated in Figure-1, results showed that $\mathrm{PPR} / \mathrm{BT}$ represents the highest percentages, while the FMD/BT represents the lowest one when compared with the corresponding total numbers. FMD/BT showed moderate percentages. These results indicate that PPR and BT are endemic in the two governorates more than FMD. In each governorate, the antibodies prevalence $\mathrm{PPR} / \mathrm{BT}$ is more in sheep than in goats. This is due to the high susceptibility of goats to PPR than sheep. In comparison with the two governorates, Giza possesses a higher percentage of antibodies prevalence against PPR/BT (12.85\%) than Beni-Suef $(10 \%)$ in goats. Giza possesses a lower percentage of antibodies prevalence against PPR/BT (17.69\%) than Beni-Suef (23.33\%) in sheep. This result could be interpreted, as at the individual level, the total prevalence of antibodies against both PPR and BT was higher in Beni-Suef $(61 \%$ and $70 \%)$ than in Giza $(57.5 \%$ and $42 \%$ ) for sheep and goats collectively.

Results showed large number of positive sheep $(10 \%)$ to $\mathrm{FMD} / \mathrm{PPR} / \mathrm{BT}$ in Beni-Suef than Giza (3.8\%). Giza possesses a higher percentage of antibodies against FMD/PPR/BT (5.7\%) than Beni-Suef $(5 \%)$ in goats. The total positive sheep and goats to $\mathrm{FMD} / \mathrm{PPR} / \mathrm{BT}$ were lower in Giza $(4.5 \%)$ than in Beni-Suef (8\%).

The maximum single seroprevalence was in PPR infection 39/130 (30\%) and the maximum double seroprevalence was observed in PPR/BT infection 23/130 (17.69\%) as shown in Table-1.

\section{Conclusion}

The examined governorates were endemic with FMD, PPR, and BT. Therefore, sheep and goats may transmit such viruses to contact farm animals and remain infective for long time without detectable clinical signs. Thus, sheep and goats may play a role in the persistence and transmission of different viral infection.

Regional plan for combating FMD is recommended. Full characterization of FMD strains is important, as it helps in the achievement to the most suitable combination of the vaccine formula. Sheep and goats must be included in FMD vaccination program. Mixed breeding between different species of livestock is an obstacle in the control operations and a means of transmitting diseases between these species such as BT. Sheep and goats may pick up the infection due to their presence next to cows, which are the main reservoir of the BTV. We are in need for further new studies for identification and characterization of the circulating BT strains in Egypt. Moreover, special attention should be considered to avoid importation of animals from the countries in which recent outbreaks of FMD, PPR, and BT occurred.

\section{Authors' Contributions}

MAEM, MKE, DS, and SA conceived the study, carried out the laboratory work, and analyzed the data. MAEM performed the fieldwork and collected the samples. MAEM and MKE drafted the manuscript. All authors read and approved the final manuscript.

\section{Acknowledgments}

Authors would like to thank the field veterinarians who helped in collecting serum samples and Prof. Dr. Hala Abdalla (Department of Parasitology and Animal Diseases, Veterinary Research Division, National Research Center) who served FMD 3ABC of FMD ELISA kit (IDEXX FMD 3ABC Bo-Ov).

\section{Competing Interests}

The authors declare that they have no competing interests.

\section{References}

1. Chakraborty, S., Kumar, N., Dhama, K., Verma, A.K., Tiwari, R., Kumar, A., Kapoor, S. and Singh, S.V. (2014) Foot-and-mouth disease, an economically important disease of animals. Adv. Anim. Vet. Sci., 2: 1-18.

2. Kumar, A., Rahal, A., Chakraborty, S., Verma, A.K. and Dhama, K. (2014) Mycoplasma agalactiae, an etiological agent of contagious agalactia in small ruminants - A review. Vet. Med. Int., 2014: Article ID: 286752, 13.

3. Chakraborty, S., Kumar, A., Tiwari, R., Rahal, A., Malik, Y., Dhama, K., Pal, A. and Prasad, M. (2014) Advances in diagnosis of respiratory diseases of small ruminants, Hindawi Publishing Corporation. Vet. Med. Int., 2014, Article ID: 508304,16.

4. Grubman, M.J. and Baxt, B. (2004) Foot-and-mouth disease. Clin. Microbiol. Rev., 17(2): 465-493.

5. FAO. (2012) Foot-and-Mouth Disease Situation Monthly Report June 2012. Available from: http://www.fao.org/fileadmin/user_upload/eufmd/docs/FMD_monthly_reports/ June2012.pdf. Accessed on 20-06-2016.

6. Weaver, G.V., Domenech, J., Thiermann, A.R. and Karesh, W.B. (2013) Foot and mouth disease: A look from the wild side. J. Wildlife Dis., 49(4): 759-785.

7. Alexandersen, S., Zhang, Z., Donaldson, A.L. and Garland, A.J.M. (2003) The pathogenesis and diagnosis of foot and mouth disease. J. Compr. Pathol., 129: 268-282.

8. Sikombe, T.K.W., Mweene, A.S., JohnMuma, C., Kasanga, Y., Sinkala, F., Banda, F., Mulumba, M., Fana, E.M., Mundia, C. and Simuunza, M. (2015) Serological survey of foot-and-mouth disease virus in buffaloes (Syncerus caffer) in Zambia. Vet. Med. Int., 2015, Article ID: 264528,8 .

9. Mohamed, F., Swafford, S., Petrowski, H., Bracht, A., Schmit, B., Fabian, A., Pacheco, J.M., Hartwig, E., Berninger, M., Carrillo, C., Mayr, G., Moran, K., Kavanaugh, D., Leibrecht, H., White, W. and Metwally, S. (2011) Foot-andmouth disease in feral swine: Susceptibility and transmission. Transbound. Emerg. Dis., 58(4): 358-371.

10. Chen, H. and Liu, Y. (2013) Immunity of foot-and-mouth disease serotype Asia 1 by sublingual vaccination. PLoS 
One, 8(5): 0063839.

11. Onono, J.O., Wieland, B. and Rushton, J. (2013) Constraints to cattle production in a semi-arid pastoral system in Kenya. Trop. Anim. Health Prod., 45: 1415-1422.

12. Park, J.H. (2013) Requirements for improved vaccines against foot-and-mouth disease epidemics. Clin. Exp. Vaccine Res., 2: 8-18.

13. Clavijo, A., Zhou, E.M., Hole, K., Galic, B. and Kitching, P. (2004) Development and use of a biotinylated 3ABC recombinant protein in a solid-phase competitive ELISA for the detection of antibodies against foot-and-mouth disease virus. J. Virol. Methods, 120: 217-227.

14. Banyard, A.C., Wang, Z. and Parida, S. (2014) Peste des petits ruminants virus, Eastern Asia. Emerg. Infect. Dis., 20: 2176-2177.

15. Braide, V.B. (1981) Peste des petits ruminants. World Anim. Rev., 39: 25-28.

16. Parida, S., Muniraju, M., Mahapatra, M., Muthuchelvan, D., Buczkowski, H. and Banyard, A.C. (2015) Peste des petits ruminants veterinary microbiology. Vet. Microbiol., 181(1-2): 90-106.

17. Libeau, G., Diallo, A. and Parida, S. (2014) Evolutionary genetics underlying the spread of paste des petites ruminant's virus. Anim. Front, 4: 14-20.

18. Taylor, W.P. (1984) The distribution and epidemiology of PPR. Prev. Vet. Med., 2: 157-166.

19. Taylor, W.P. and Barrett, T. (2007) Diseases of Sheep. $4^{\text {th }}$ ed., Ch. 61. Blackwell Publishing, Oxford, UK. p460-469.

20. Abubakar, M., Arshed, M.J., Hussain, M. and Ali, Q. (2011) Evidence of peste des petits ruminants in serology of sheep and goats from Sindh, Pakistan. Transbound. Emerg. Dis., 58: $152-156$

21. Attoui, H., Maan, S.S., Anthony, S.J. and Mertens, P.P.C. (2009) In: Bluetongue Virus, Other Orbiviruses and other Reoviruses: Their Relationships and Taxonomy. $1^{\text {st }}$ ed. Elsevier/Academic Press, London. p23-552.

22. Maan, S., Maan, N.S., Nomikou, K., Veronesi, E., Bachanek-Bankowska, K., Belaganalli, M.N., Attoui, H. and Mertens, P.C. (2011) complete genome characterization of a novel $26^{\text {th }}$ bluetongue virus serotype from Kuwait. PLoS One, 6, e26147.

23. Mahmoud, M.A. and Khafagi, M.H. (2014) Seroprevalence of bluetongue in sheep and goats in Egypt. Vet. World, 7(4): 205-208.

24. Faes, C., van der Stede, Y., Guis, H., Staubach, C., Ducheyne, E., Hendrickx, G. and Mintiens, K. (2013) Factors affecting bluetongue serotype 8 spread in Northern Europe in 2006: The geographical epidemiology. Prev. Vet. Med., 110(2): 149-158.

25. Gard, G.P. and Melville, L.E. (1992) In: Bluetongue, African Horse Sickness and Related Orbivirases. Walton, T.E. and Osburn, B.I., editors. C.R.C. Press, Boca Raton. USA. p85.

26. MacLachlan, N.J., Drew, C.P., Darpel, K.E. and Worwa, G. (2009) The pathology and pathogenesis of blue-tongue. $J$. Comp. Pathol., 141: 1-16.

27. Hafez, S.M. and Ozawa, Y. (1973) Serological survey of bluetongue in Egypt. Bull. Epiz. Dis. Afr., 21(3): 297-304.

28. Ismail, J.M., Martin, J., Nazmi, A. (1987) Bluetongue neutralization test with different virus under variable conditions. Agric. Res. Rev. Egypt, 65(5): 867-872.

29. Paixão, T., Carvalho, A., Paiva, N., Reis, J., Barbosa, M., Serra, C., Silva, R., Beckham, T., Martin, B., Clarke, N., Adams, L. and Santos, R. (2008) Diagnosis of foot-andmouth disease by real-time reverse transcription polymerase chain reaction under field conditions in Brazil. $B M C$ Vet. Res., 4: 53.

30. EL-Bayoumy, M.K., Abdelrahman, K.A., Allam, A.M., Farag, T.K., Hala Abou-Zeina, A.A. and Kutkat, M.A. (2014) Molecular characterization of foot-and-mouth disease virus collected from Al-Fayoum and Beni - Suef governorates in Egypt. Glob. Vet., 13(5): 828-835.

31. Farougou, S., Gagara, M. and Mensah, G.A. (2013) Prevalence of peste des petits ruminants in the arid zone in the republic of Niger. Onderstepoort J. Vet. Res., 80: 544.

32. Afshar, A., Heckert, R.A., Dulac, C., Trotter, H.C. and Myers, D.J. (1995) Application of a competitive ELISA for the detection of bluetongue virus antibodies in llamas and wild ruminants. J. Wildl. Dis., 31, 327-330.

33. Available from: http://www.socscistatistics.com/tests/pearson/Default2.aspx. Accessed on 15-03-2017.

34. Sun, T., Lu, P. and Wang, X. (2004) Localization of infection-related epitopes on the non-structural protein $3 \mathrm{ABC}$ of foot-and mouth disease virus and the application of tandem epitopes. J. Virol. Methods, 119(2), 79-86.

35. Thomson, G.R. and Bastos, A.D.S. (2004) In: Coetzer, J.A.W., Tustin, R.C., editors. Foot-and-Mouth Disease, Infectious Diseases of Livestock. $2^{\text {nd }}$ ed. Oxford University Press, South Africa. p1324-1365.

36. Al-Majali, A.M., Jawasreh, K. and Nsour, A.A. (2008) Epidemiological studies on foot and mouth disease and Para tuberculosis in small ruminants in Tafelah and Ma'am, Jordan. Small Rumin. Res., 78: 197-201.

37. Balinda, S.N., Tjornehoj, K., Muwanika, V.B., Sangula, A.K., Mwiine, F.N., Ayebazibwe, C., Masembe, C., Siegismund, H.R. and Alexandersen, S. (2009) Prevalence estimates of antibodies towards foot-and-mouth disease virus in Small Ruminants in Uganda. Transbound. Emerg. Dis., 56, 362-371.

38. Ur-Rehman, S., Arshad, M., Hussain, I. and Iqbal., Z. (2014) Detection and seroprevalence of foot and mouth disease in sheep and goats in Punjab, Pakistan. Transbound. Emerg. Dis., 61 Suppl 1, 25-30.

39. Elnekavea, E., van Maanenb, K., Hila, S., Boris, G., Nick, S., Svetlane, B., Olaf, B. and Eyal, K. (2016) Prevalence and risk factors for foot and mouth disease infection in small ruminants in Israel. Prev. Vet. Med., 125: 82-88.

40. Bravo de Rueda, C., de Jong, M.C., Eble, P.L. and Dekker, A. (2014) Estimation of the transmission of footand-mouth disease virus from infected sheep to cattle. Vet. Res., 45: 58 .

41. Barnett, P.V. and Cox, S.J. (1999) The role of small ruminants in the epidemiology and transmission of foot-andmouth disease. Vet. J., 158: 6-13. Available from: http:// www.idealibrary.com. Accessed on 20-03-2017.

42. Taylor, W.P., Al-Busaidy, S. and Barrett, T. (1990) The epidemiology of peste des petits ruminants in the Sultanate of Oman. Vet. Microbiol., 22(4): 341-352.

43. Shaila, M.S., Purushothaman, V., Bhavasar, D., Venugopal, K. and Venkatesan, R.A. (1989) Paste des petites ruminants in India. Vet. Rec., 125(24): 602.

44. Roeder, P.L., Abraham, G., Kenfe, G. and Barrett, T. (1994) PPR in Ethiopian goats. Trop. Anim. Health Prod., 26: 69-73.

45. Elshemey, T.M. and Mahmoud M.A. (2011) Seroprevalence of antibodies against peste des petits ruminants (PPR) virus in sheep and goat in kingdom Saudi Arabia. Alex. J. Vet. Sci., 32(1): 175-182.

46. Luedke, A.J. and Anakwenze, E.1. (1972) Bluetongue virus in goats. Am. J. Vet. Res., 33(9): 1739-1745.

47. Mahmoud, M.A. and Galbat, S.A. (2017) Outbreak of foot and mouth disease and peste des petits ruminants in sheep flock imported for immediate slaughter in Riyadh. Vet. World, 10(2): 238-243.

48. Miller, M.M., Brown, J., Cornish, T., Johnson, G., Mecham, J.O., Reeves, W.K. and William, W. (2010) Investigation of a bluetongue disease epizootic caused by bluetongue virus serotype 17 in sheep in Wyoming. J. Am. Vet. Med. Assoc., 237(8): 955-959. 